Open Access

\title{
Prescribed fire alters structure and composition of a mid-Atlantic oak forest up to eight years after burning
}

\author{
Cody L. Dems ${ }^{1 *} \mathbb{D}$, Alan H. Taylor², Erica A. H. Smithwick², Jesse K. Kreye ${ }^{1}$ and Margot W. Kaye ${ }^{1}$
}

\begin{abstract}
Background: Prescribed fire in Eastern deciduous forests has been understudied relative to other regions in the United States. In Pennsylvania, USA, prescribed fire use has increased more than five-fold since 2009, yet forest response has not been extensively studied. Due to variations in forest composition and the feedback between vegetation and fire, Pennsylvania deciduous forests may burn and respond differently than forests across the eastern US. We measured changes in forest structure and composition up to eight years after prescribed fire in a hardwood forest of the Ridge and Valley region of the Appalachian Mountains in central Pennsylvania.

Results: Within five years post fire, tree seedling density increased more than $72 \%$ while sapling density decreased by $90 \%$, midstory density decreased by $46 \%$, and overstory response varied. Following one burn in the mixed-oak unit, overstory tree density decreased by 12\%. In the aspen-oak unit, where pre-fire harvesting and two burns occurred, overstory tree density increased by $25 \%$. Not all tree species responded similarly and post-fire shifts in species relative abundance occurred in sapling and seedling size classes. Abundance of red maple and cherry species decreased, whereas abundance of sassafras, quaking aspen, black oak, and hickory species increased.
\end{abstract}

Conclusions: Forest composition plays a key role in the vegetation-fire relationship and localized studies are necessary to measure forest response to prescribed fire. Compositional shifts in tree species were most pronounced in the aspen-oak unit where pre-fire overstory thinning and two prescribed fires were applied and significant structural changes occurred in all stands after just one burn. Increases in fire-tolerant tree species combined with reductions in fire-intolerant species highlight the role of prescribed fire in meeting management objectives such as altering forest structure and composition to improve game habitat in midAtlantic hardwood forests.

Keywords: Acer, fire management, hardwood forest, post-fire tree mortality, Quercus, Ridge and Valley

\footnotetext{
* Correspondence: codydems@hotmail.com

'Department of Ecosystem Science and Management, The Pennsylvania

State University, University Park, Pennsylvania 16802, USA

Full list of author information is available at the end of the article
}

\section{Springer Open}

(c) The Author(s). 2021 Open Access This article is licensed under a Creative Commons Attribution 4.0 International License, which permits use, sharing, adaptation, distribution and reproduction in any medium or format, as long as you give appropriate credit to the original author(s) and the source, provide a link to the Creative Commons licence, and indicate if changes were made. The images or other third party material in this article are included in the article's Creative Commons licence, unless indicated otherwise in a credit line to the material. If material is not included in the article's Creative Commons licence and your intended use is not permitted by statutory regulation or exceeds the permitted use, you will need to obtain permission directly from the copyright holder. To view a copy of this licence, visit http://creativecommons.org/licenses/by/4.0/. 


\section{Resumen}

Antecedentes: Las quemas prescriptas en los bosques deciduos del Este, han sido poco estudiadas en relación a otras regiones en los Estados Unidos. En Pensilvania, EEUU, las quemas prescriptas se han incrementado más de cinco veces desde 2009, aunque sus respuestas en los bosques no han sido extensivamente estudiadas. Debido a variaciones en la composición del bosque y a la retroalimentación entre fuego y vegetación, los bosques deciduos de Pensilvania pueden quemarse y responder demanera diferente que otros bosques a través del Este de los EEUU. Medimos cambios en la composición y estructura del bosque hasta ocho años después de una quema prescripta en un bosque de la región del valle de las montañas Ridge en los Apalaches del centro de Pensilvania.

Resultados: Dentro de los cinco años post incendio, la densidad de plántulas se incrementó más del 72\%, la densidad de brinzales (árboles jóvenes) decreció en un 90\%, la densidad del sotobosque de media altura decreció en un $46 \%$ y la respuesta del dosel superior fue variable. Después de una quema en la unidad de roble-álamo, la densidad del dosel superior decreció en un 12\%. En la unidad de roble-álamo, donde se realizó una corta pre fuego y luego dos quemas, la densidad del doselsuperior se incrementó en un $25 \%$. No todas las especies respondieron de manera similar y desviaciones en la abundancia relativa de especies ocurrieron en tamaños y clases de edad de plántulas y brinzales. La abundancia del arce rojo y de especies de cerezo decrecieron, mientras que aumentó la abundancia de especies como el sasafrás, álamo temblón, roble negro y nogal americano.

Conclusiones: La composición del boque juega un rol clave en la relación fuego-vegetación, y estudios localizados son necesarios para medir la respuesta del bosque a lasquemas prescriptas. Las desviaciones en la composición de especies fueron más pronunciadas en la unidad de roble-álamo, donde un raleo pre fuego del dosel superior y dos quemas prescriptas fueron aplicadas, ocurriendo cambios estructurales significativos en todos los rodales con solo una quema. El incremento de especies de árboles tolerantes al fuego combinado con la reducción de especies intolerantes alfuego, destaca el rol de las quemas prescriptas en la consecución de objetivos de manejo, como la alteración de la estructura del bosque y su composición para mejorar el hábitat para la fauna en los bosques Atlánticos de madera dura de los EEUU.

\section{Background}

Prescribed fires are planned disturbances used to influence forest structure and composition with varying effects across regions (Ryan et al. 2013). Prescribed fire is relatively understudied in the eastern deciduous forests of the United States (Stambaugh et al. 2015; Varner et al. 2016), yet fire is increasingly used for management purposes. For example, the State of Pennsylvania passed the Prescribed Burning Practices Act in 2009, reducing the legal barriers placed on the use of prescribed fire within the state (Pennsylvania General Assembly 2009). This policy change supports the desires of multiple land agencies to use prescribed fire to promote specific forest compositions for ecological and economic benefit (Brose et al. 2008; Pennsylvania General Assembly 2009). In the seven years following the legislation, the annual number of prescribed fires in Pennsylvania increased from 56 to 222, and area burned increased from 1107 to 7532 ha (PA DCNR 2015; National Interagency Fire Center 2017), many hectares burning only once due to the barriers forest managers face when planning and implementing prescribed fires (Smithwick et al. 2020). This influx of prescribed fire is introducing disturbance to areas that have been fire free for about 80 years (Klimkos 2017), and localized forest response has not been extensively studied.

Over the past century, Eastern oak (Quercus spp.) forests experienced a shift in species abundance with increases in fire-intolerant species such as red maple (Acer rubrum L.) and limited regeneration of fire-tolerant oak (Abrams 2003; Nowacki and Abrams 2008). Reduced oak dominance is a management concern due to declines in wildlife habitat quality (Brose et al. 2008; Dey 2014), timber market stability (Brose et al. 2008), nutrient cycling (Alexander and Arthur 2010; Alexander and Arthur 2014), and understory plant diversity (Hutchinson et al. 2005). While multiple interacting factors are driving this forest change (McEwan et al. 2011), research indicates that humans played a significant role in altering the type and extent of forest disturbance (Drummond and Loveland 2010) to include landscape-scale forest clearing and homogenization of forest age (Dey 2014) as well as decreasing fire frequency (Stambaugh et al. 2018; Abrams and Nowacki 2019). Both indigenous peoples and European settlers set fires, but early twentieth century policy required all fires to be suppressed, which abruptly curbed human ignitions (Donovan and Brown 2007; Marschall et al. 2016; Lafon et al. 2017). Prescribed fire is considered a tool to reinstate disturbance in Eastern forests (Brose 2014), an idea that stems from a historical relationship between frequent fire and oak dominance (Nowacki and Abrams 2008).

One way prescribed fire alters forests is by killing trees and promoting new germination and growth. Most post- 
fire tree death occurs in smaller-diameter trees due to the combination of mild burn conditions (Schwilk et al. 2009) and increased fire resistance as trees get larger (Brando et al. 2012). Following prescribed fire, top-killed or injured trees of certain species use below-ground energy stores to re-sprout (Huddle and Pallardy 1999; Blankenship and Arthur 2006), and fire promotes seedling germination by consuming surface fuels, which reduces litter and duff depth (Graham and McCarthy 2006; Arthur et al. 2012; Arthur et al. 2017). Additionally, fire promotes seedling growth with temporary increases in light availability due to canopy thinning (Alexander et al. 2008). However, the extent of tree death and regrowth is dependent on time of year (Huddle and Pallardy 1999; Knapp et al. 2009), number and frequency of fires (Keyser et al. 2017), direct and indirect fire effects (Hood et al. 2018), pre-fire management (Albrecht and McCarthy 2006; Schwilk et al. 2009), landscape position (Iverson et al. 2008; Arthur et al. 2015), and tree species (Fan et al. 2011; Keyser et al. 2018). Species in Eastern forests have traits that influence their response to fire (Fan et al. 2011; Keeley et al. 2011; Pausas 2015). For example, many oak species have thicker bark, more flammable leaf litter, and greater below-ground energy stores than red maple, effectively increasing their survival and promoting fire where they are dominant (Abrams 2003; Kreye et al. 2013). Variation in species composition contributes to a feedback by which vegetation influences flammability and fire effects, and fire effects influence future vegetation (Nowacki and Abrams 2008; Mitchell et al. 2009; Tiribelli et al. 2018).

In this study, we ask how prescribed fire affects midAtlantic deciduous forests over time. To answer this, we measured changes in forest structure (abundance in tree size classes) and composition in the Ridge and Valley Region of the Appalachian Mountains in central Pennsylvania up to eight years after prescribed fire. We hypothesized that (H1) following one or two dormantseason prescribed fires, there would be a pulse of seedling and sprout recruitment, but a reduction of living sapling and canopy trees; and that $(\mathrm{H} 2)$ the relative abundance of fire-tolerant tree species would increase following prescribed fire due to higher survival and regeneration relative to fire-intolerant trees. Our results expand existing knowledge of Eastern deciduous forest response to prescribed fire for multiple tree species in mixed-deciduous forests of the mid-Atlantic.

\section{Methods}

\section{Study site}

Fire effects were studied on Pennsylvania State Game Lands 176 (SGL176) in the Ridge and Valley Physiographic Province of central Pennsylvania $\left(40.7^{\circ} \mathrm{N}, 77.9^{\circ} \mathrm{W}\right)$. SGL176 has a humid continental climate with 80 to $100 \mathrm{~cm}$ of annual precipitation and averages $9.4{ }^{\circ} \mathrm{C}$ throughout the year (calculated from State College data, 7 km away; The Pennsylvania State Climatologist 2019). SGL176 is about $400 \mathrm{~m}$ above sea level and located in a valley floor "frost pocket," where cold air pools as it sinks from surrounding ridges (O’Neil 2006). Soils are well drained, acidic sandy loams (USDA Web Soil Survey 2019) and land use has varied over the past 200 years, including eras of iron ore mining and charcoal production (O'Neil 2006; Abrams and Johnson 2014), as well as extensive logging and human-caused fires from these activities.

To measure prescribed fire effects in SGL176, we sampled vegetation before and after burning (between 2009 and 2018). All fires were ignited by hand in spring before leaf out, conducted by the Pennsylvania Game Commission (PGC) under pre-established prescription parameters (Additional file 1), and intended to improve wildlife habitat. Forests in this area had not burned since 1939 (Klimkos 2017). Prescribed fire was applied in two units, identified here as mixed-oak and aspen-oak based on pre-fire overstory dominance (Fig. 1). The mixed-oak unit totaled 108 ha and was burned in three sections during 2010 to promote mixed oak-hickory (Carya Nutt. spp.) stands by reducing maple (Acer L. spp.), birch (Betula spp.), and aspen (Populus L. spp.) regeneration. The aspen-oak unit was 28 ha and burned in both 2014 and 2017 to restore scrub oak (Quercus ilicifolia Wangenh.)-pitch pine (Pinus rigida P. Mill) communities. Before prescribed fire use, the aspen-oak unit was actively managed for ruffed grouse (Bonasa umbellus Linnaeus, 1766) habitat using checkerboard mowing and overstory tree removal (alternating one-hectare squares; Palmer 2000). To identify forest changes related to prescribed fire versus those already occurring in the forest, we compared data from the two burn units to data from unburned forests in SGL176 using monitoring data from the PGC's Continuous Forest Inventory (CFI). CFI plots occur throughout PGC lands, were located in $\geq 20$-year-old forests, and provided comparable metrics. SGL176 had three CFI plots for comparison.

Pre-fire tree species composition for the burn units and unburned plots are provided in Table 1, and initial tree density and basal area measures are presented in Fig. 2. Ground cover in the study area consisted of scattered fern (including Pteridium aquilinum [L.] Kuhn, Dryopteris carthusiana [Vill.] H.P. Fuchs, and Dennstaedtia punctilobula [Michx.] T. Moore) and lowbush blueberry (Vaccinium L. spp.) patches. Clusters of invasive privet (Ligustrum obtusifolium Siebold \& Zucc.), bush honeysuckles (including Lonicera maackii [Rupr.] Herder, Lonicera tatarica L., and Lonicera $\times$ bella Zabel), and Japanese barberry (Berberis thunbergii DC) were scattered throughout the forest, and extensive deer browse created understory conditions such that 


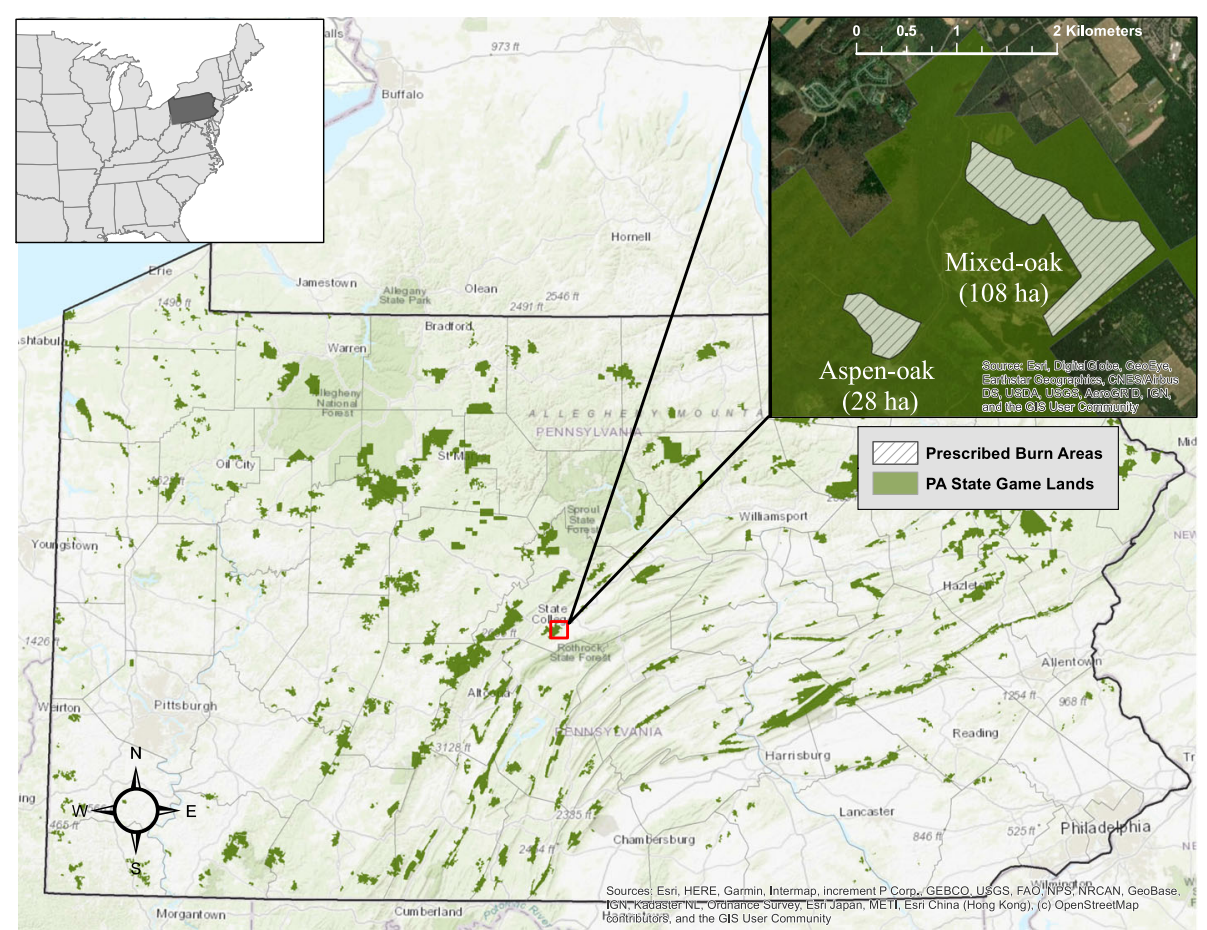

Fig. 1 Map of study area within State Game Lands 176, in central Pennsylvania, USA, where we measured changes in forest structure and composition after prescribed fire, between 2009 and 2018

hardwood leaf litter was the primary ground cover. In addition, the aspen-oak unit had a large shrub component of scrub oak and dwarf chestnut oak (Quercus prinoides Willd.).

\section{Field measurements}

Within the burned units, field measurements began the summer prior to the initial burn and the same protocols were repeated at various intervals for five to eight years after fire (mixed-oak unit measured in 2009, 2010, 2015, and 2018; aspen-oak unit measured in 2013, 2015, and 2018). All measurements were completed between 1 May and 31 August to capture growing season vegetation. Nested fixed area plots $(12.6 \mathrm{~m}$ radius for overstory and midstory; $4 \mathrm{~m}$ for saplings; four $1.3 \mathrm{~m}$ for seedlings) were established within each burn unit using a systematic sampling design (mixed-oak, $n=44$; aspen-oak, $n=$ 10 [five of which were mowed or thinned pre fire]). Plots were located at least $60 \mathrm{~m}$ from unit boundaries and the number of plots in each burn unit was determined by unit size.

To measure forest structure and composition change over time, all living trees $>5 \mathrm{~cm}$ tall were identified to species (to genus by some observers) and their diameter at breast height $(\mathrm{DBH})$ recorded with $0.1 \mathrm{~cm}$ accuracy. When seedling trees (seedlings, sprouts, and suckers $\leq 2.54 \mathrm{~cm} \mathrm{DBH}$ ) were growing from the same base, only the three largest were recorded. Unburned forest plots were measured twice, in 2009 and 2014, using the PGC's CFI protocols (Bureau of Wildlife Habitat Management 2013) and slightly larger vegetation plots $(16.1 \mathrm{~m}$ radius for overstory and midstory; $8 \mathrm{~m}$ for saplings; $1.3 \mathrm{~m}$ for seedlings) than those in the burn units.

\section{Data analysis \\ Forest structure}

To quantify changes in forest structure, we used linear mixed-effects models (Bates et al. 2015; R Core Team 2018) to compare living tree stem density and basal area across years. We treated year as a categorical fixed effect, independent variable and modeled mean values at the plot level. To account for the variation across plots, we included plot as a random effect and, when present, nested subplots within each plot (seedling measurements). A few plots could not be relocated during at least one year of data collection so our analysis only includes plots measured at all time points (mixed-oak, $n=$ 40; aspen-oak, $n=7$; unburned, $n=3$ ). A small portion of the mixed-oak unit $(<10 \%)$ was affected by an aspen harvest prior to burning; however, there were too few plots $(n=2)$ included in the harvested area to analyze them separately. Yearly differences of each response variable were analyzed with Tukey pairwise comparisons using least-squares means (Lenth 2016). All statistical tests were considered significant at $\alpha=0.05$. 
Table 1 Pre-fire tree species composition by tree size class within State Game Lands 176, Pennsylvania, USA, where we measured post-fire changes in forest structure and composition between 2009 and 2018

\begin{tabular}{|c|c|c|c|c|c|}
\hline & & \multicolumn{4}{|c|}{ Pre-fire composition (\% of total trees) } \\
\hline & & \multirow{2}{*}{$\begin{array}{l}\text { Seedlings } \\
>5.08 \mathrm{~cm} \text { tall, }<2.54 \mathrm{~cm} \\
\text { DBH }\end{array}$} & \multirow{2}{*}{$\begin{array}{l}\text { Saplings } \\
2.54-10.15 \mathrm{~cm} \\
\text { DBH }\end{array}$} & \multirow{2}{*}{$\begin{array}{l}\text { Midstory } \\
10.16-19.99 \mathrm{~cm} \\
\text { DBH }\end{array}$} & \multirow{2}{*}{$\begin{array}{l}\text { Overstory } \\
>19.99 \mathrm{~cm} \\
\text { DBH }\end{array}$} \\
\hline & & & & & \\
\hline \multicolumn{6}{|c|}{ Unburned (measured 2009) } \\
\hline Bigtooth aspen & Populus grandidentata Michx. & - & - & 22.2 & 27.4 \\
\hline Birch & Betula spp. & - & - & 1.9 & - \\
\hline Black oak & Quercus velutina Lam. & 5.6 & - & - & 8.3 \\
\hline Cherry & Prunus L. spp. & - & - & 3.7 & - \\
\hline Dogwood & Cornus L. spp. & - & 4.2 & - & - \\
\hline Hickory & Carya spp. & 3.7 & - & 3.9 & 2.8 \\
\hline Northern red oak & Quercus rubra L. & 5.7 & - & - & 13.2 \\
\hline Red maple & Acer rubrum L. & 73.7 & 70.8 & 50.9 & 11.5 \\
\hline Sassafras & Sassafras albidum (Nutt.) Nees & - & - & 4.2 & 2.8 \\
\hline Serviceberry & Amelanchier Medik. spp. & 0.4 & 12.5 & - & - \\
\hline White oak & Quercus alba L. & 11.0 & 8.3 & 13.2 & 34.0 \\
\hline \multicolumn{6}{|c|}{ Mixed-oak (measured 2009) } \\
\hline $\begin{array}{l}\text { American } \\
\text { chestnut }\end{array}$ & $\begin{array}{l}\text { Castanea dentata (Marsh.) } \\
\text { Borkh. }\end{array}$ & 0.1 & - & - & - \\
\hline Bigtooth aspen & Populus grandidentata & 0.4 & 0.7 & 2.9 & 14.3 \\
\hline Birch & Betula spp. & 0.4 & - & 0.7 & 0.5 \\
\hline Blackgum & Nyssa sylvatica Marshall & 0.3 & 0.7 & - & - \\
\hline Black oak & Quercus velutina & 3.9 & 4.9 & 2.0 & 10.7 \\
\hline Cherry & Prunus spp. & 3.4 & 0.7 & 0.9 & 0.6 \\
\hline Chestnut oak & Quercus montana Willd. & 11.5 & 6.5 & 4.4 & 11.9 \\
\hline Dogwood & Cornus spp. & 0.1 & - & - & - \\
\hline $\begin{array}{l}\text { Eastern white } \\
\text { pine }\end{array}$ & Pinus strobus L. & - & - & 0.9 & - \\
\hline Hickory & Carya spp. & 2.9 & 0.4 & 23.9 & 5.6 \\
\hline Northern red oak & Quercus rubra & 9.0 & 2.9 & - & 2.7 \\
\hline Pitch pine & Pinus rigida MIII. & - & - & 0.3 & 0.9 \\
\hline Red maple & Acer rubrum & 46.4 & 71.2 & 33.8 & 15.9 \\
\hline Sassafras & Sassafras albidum & 14.0 & 3.1 & 21.8 & 2.4 \\
\hline Scarlet oak & Quercus coccinea Muenchh. & 0.4 & 1.6 & 1.5 & 10.7 \\
\hline Serviceberry & Amelanchier spp. & 0.1 & - & - & - \\
\hline Striped maple & Acer pensylvanicum $\mathrm{L}$. & 0.1 & - & - & - \\
\hline Sugar maple & Acer saccharum Marshall & - & - & 0.6 & - \\
\hline White oak & Quercus alba & 7.1 & 6.0 & 7.4 & 23.8 \\
\hline \multicolumn{6}{|c|}{ Aspen-oak (measured 2013) } \\
\hline Bigtooth aspen & Populus grandidentata & - & 4.8 & 12.4 & 37.2 \\
\hline Black oak & Quercus velutina & 0.3 & 7.1 & 0.8 & 2.4 \\
\hline Cherry & Prunus spp. & 22.4 & 26.6 & 54.1 & 26.3 \\
\hline Dogwood & Cornus spp. & 1.4 & 1.3 & - & - \\
\hline Hawthorn & Crataegus Tourn. ex L. spp. & 0.2 & - & - & - \\
\hline Hickory & Carya spp. & 0.6 & 1.8 & - & - \\
\hline
\end{tabular}


Table 1 Pre-fire tree species composition by tree size class within State Game Lands 176, Pennsylvania, USA, where we measured post-fire changes in forest structure and composition between 2009 and 2018 (Continued)

\begin{tabular}{|c|c|c|c|c|c|c|c|c|c|}
\hline & & \multicolumn{8}{|c|}{ Pre-fire composition (\% of total trees) } \\
\hline & & \multirow{2}{*}{$\begin{array}{l}\text { Seedlings } \\
>5.08 \mathrm{~cm} \text { tall, }<2.54 \mathrm{~cm} \\
\text { DBH }\end{array}$} & & \multirow{2}{*}{\multicolumn{2}{|c|}{$\begin{array}{l}\text { Saplings } \\
2.54-10.15 \mathrm{~cm} \\
\text { DBH }\end{array}$}} & \multirow{2}{*}{$\begin{array}{l}\text { Midstory } \\
10.16-19.99 \mathrm{~cm} \\
\text { DBH }\end{array}$} & \multirow{2}{*}{\multicolumn{3}{|c|}{$\begin{array}{l}\text { Overstory } \\
>19.99 \mathrm{~cm} \\
\text { DBH }\end{array}$}} \\
\hline & & & & & & & & & \\
\hline Northern red oak & Quercus rubra & & 1.0 & & 0.4 & & - & & - \\
\hline Pitch pine & Pinus rigida & & - & & - & & - & & 5.6 \\
\hline Quaking aspen & Populus tremuloides Michx. & & - & & - & & 4.8 & & - \\
\hline Red maple & Acer rubrum & & 70.7 & & 18.3 & & 7.8 & & - \\
\hline Scarlet oak & Quercus coccinea & & 0.2 & & 19.0 & & 2.6 & & 9.5 \\
\hline Serviceberry & Amelanchier spp. & & 1.6 & & - & & - & & - \\
\hline Spruce & Picea Mill. spp. & & - & & 1.8 & & - & & - \\
\hline White oak & Quercus alba & & 1.4 & & 19.8 & & 17.5 & & 19.0 \\
\hline
\end{tabular}

Changes in live stem density and basal area were modeled separately within each forest type (mixed-oak, aspen-oak, unburned) and tree size class (seedlings, saplings, midstory, overstory). Tree size classes were designated based on sampling protocols and review of similar studies. Seedlings were $<2.54 \mathrm{~cm} \mathrm{DBH},>5.08 \mathrm{~cm}$ tall, and had at least two leaves not bearing cotyledons; saplings were 2.54 to $10.15 \mathrm{~cm} \mathrm{DBH}$; midstory trees were 10.16 to $19.99 \mathrm{~cm} \mathrm{DBH}$; and overstory trees were stems $\geq 20 \mathrm{~cm}$ DBH. Seedling stem diameter was not measured and therefore seedling basal area was not calculated. Sapling trees were grouped in $2.54 \mathrm{~cm} \mathrm{DBH}$ size classes and basal area was calculated using the median diameter of stems in each class. Stem density and basal area measures were log transformed, to satisfy assumptions of
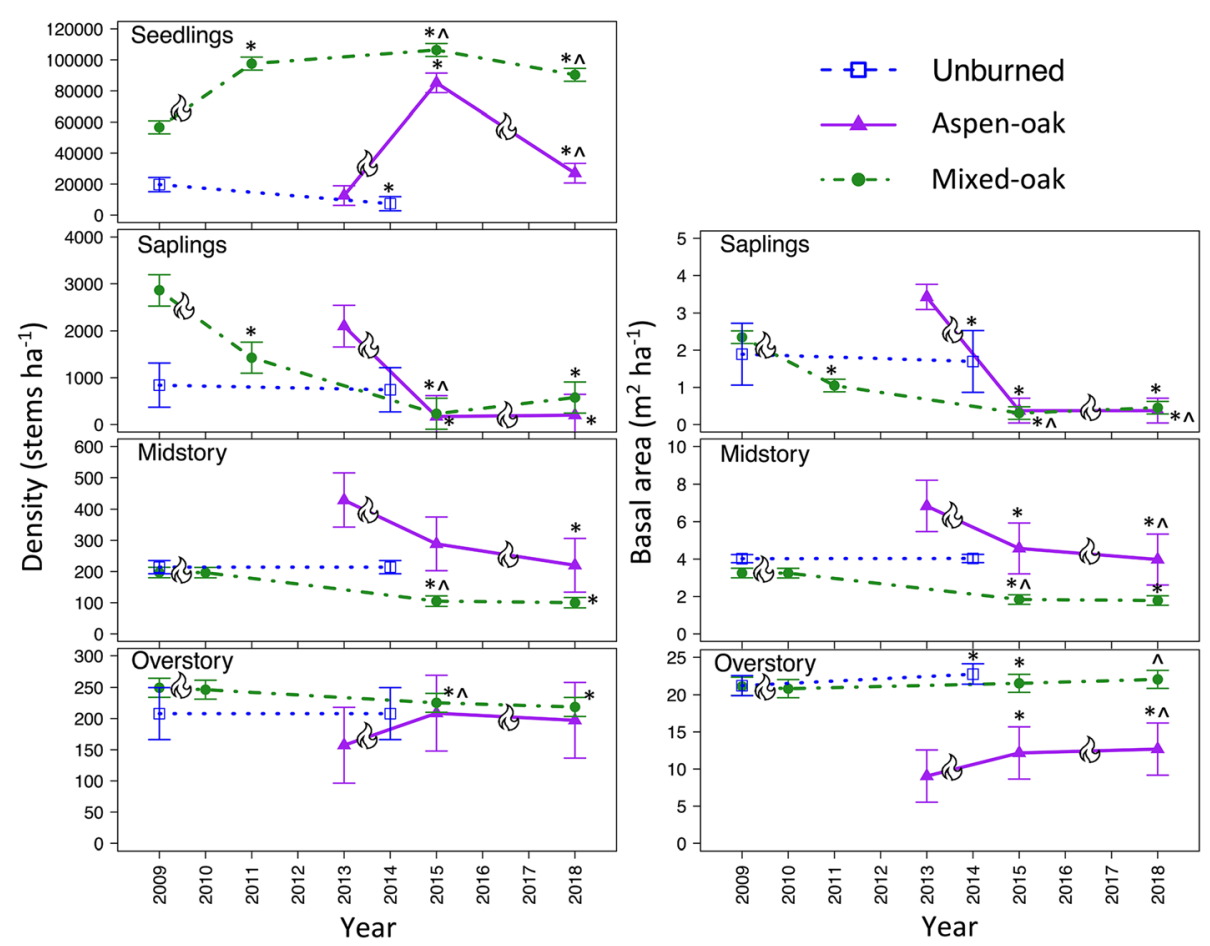

Fig. 2 Absolute density (stems ha $\left.{ }^{-1}\right)$ and basal area $\left(\mathrm{m}^{2} \mathrm{ha}^{-1}\right)$ in the unburned, aspen-oak, and mixed-oak units of State Game Lands 176, Pennsylvania, USA, where we measured post-fire changes in forest structure and composition between 2009 and 2018. Fire symbol (as) indicates the years that prescribed fire occurred in each unit. Yearly differences were determined using linear-mixed effects models and Tukey pairwise comparisons. Asterisk (*) indicates that the mean is significantly different from the initial measurement. Caret $(\wedge)$ indicates that the mean is significantly different than the previous measurement. Error bars represent standard error of the mean. Statistics were tested on log transformed data and graphs show untransformed data. Note $y$-axis numbers vary by tree size class 
homoscedasticity and normality, for statistical analysis. To account for zero values, due to the absence of trees at some size classes and some years, $\log (x+1)$ was used.

\section{Forest composition}

To evaluate change in species abundance following prescribed fire, the relative density of each species within each size class was calculated by sampling year. To determine shifts in individual species abundance, initial relative densities of each species in each plot were subtracted from those of the most recent collection. Plot-level differences were averaged to calculate mean and standard error over the management unit. In half of the burned plots, there were no living sapling trees post fire and these plots were removed from the sapling portion of forest composition analysis as relative abundance cannot be calculated when no trees are present. To explore change in species groups over time, most trees were grouped by species, but genus level classification was used for hickories (Carya spp.; a combination of Carya glabra P. Mill and Carya tometosa Nutt.), cherries (Prunus spp.; mostly Prunus serotina Ehrh. and some Prunus pensylvanica L.f.), birch (Betula spp.; primarily Betula lenta L. with small numbers of Betula papyrifera Marshall), dogwood (Cornus spp.; a mixture of Cornus amomum Mill., Cornus racemosa Lam., and Cornus florida L.), and serviceberry (Amelanchier spp.; largely Amelanchier arborea Michx.), since some field observers only identified to the genus level. Species-specific shifts were deemed notable when one standard error of the mean change in relative density did not include zero.

\section{Results}

\section{Forest structure}

The largest structural changes following prescribed fire were observed in the seedling and sapling layers with less pronounced shifts in the midstory and overstory (Fig. 2). Following a single prescribed fire (year 2010 in mixed-oak and 2014 in aspen-oak), both burn units showed large increases in seedling density two years post fire. Seedling density in the aspen-oak unit increased by more than six-fold between 2013 and 2015 $(P<0.0001)$ and mixed-oak unit seedling density increased by $72 \%$ between 2009 and $2011(P<0.0001)$. In both units, mean post-fire seedling densities were between 78000 and 102000 stems ha ${ }^{-1}$. The cohort of post-fire seedling regeneration remained over the course of eight years in the single burn mixed-oak unit. However, a second fire in the aspen-oak unit significantly reduced seedling density $(P<0.0001)$, but seedling density remained more than $100 \%$ greater than before any fire.

Prior to prescribed fire, there were more sapling stems in both the aspen-oak (2103 stems ha ${ }^{-1}$ ) and mixed-oak (2862 stems $\mathrm{ha}^{-1}$ ) units than on the unburned inventory sites $\left(840\right.$ stems $\left.\mathrm{ha}^{-1}\right)$. However, within two growing seasons post fire, both burned units had fewer saplings than the unburned sites and between 50 and 92\% fewer saplings than were initially present (Fig. 2). Sapling density in unburned plots did not change over the measurement period (between 2009 and 2014; $P=0.29$ ). In addition to post-fire reductions in sapling density, following one prescribed fire, sapling basal area in both burned units dropped 87 to $89 \%$ (below $0.4 \mathrm{~m}^{2} \mathrm{ha}^{-1}$ ), while the unburned sites remained at $1.7 \mathrm{~m}^{2} \mathrm{ha}^{-1}$ during the same years.

Living midstory stem density did not change on the unburned sites but decreased in both burned units (Fig. 2). Midstory stem densities in the burned units were not statistically different from pre-fire measurements prior to the fifth growing season, at which point midstory stem density in both burned units decreased by 46 to $48 \%(P<0.05)$. Further reductions in midstory stem density occurred in the mixed-oak unit between years five and eight; however, these changes were minor and statistically insignificant $(P=0.98)$. Midstory basal area responded similarly and decreased following prescribed fire $(P<0.001)$ by a total of $45 \%$ in the mixed-oak unit and $42 \%$ in the aspen-oak unit.

Overstory structural change varied by burn unit (Fig. 2). Between the initial and final measurements, overstory stem density remained the same on the unburned sites (208 stems ha ${ }^{-1}$ ); slightly but insignificantly increased, through successional ingrowth, in the aspen-oak unit (from 157 to 197 stems $^{-1}, P=0.25$ ); and decreased in the mixed-oak unit within six years post burn (from 249 to 218 stems $\left.\mathrm{ha}^{-1}, P<0.01\right)$. At the same time, overstory basal area had minor increases on unburned sites (from 21.2 to $22.8 \mathrm{~m}^{2} \mathrm{ha}^{-1}, P>0.05$ ) and in the mixedoak unit (from 21.1 to $22.1 \mathrm{~m}^{2} \mathrm{ha}^{-1}, P=0.74$ ) but, following two fires, increased by $40 \%$ in the aspen-oak unit (9.0 to $\left.12.7 \mathrm{~m}^{2} \mathrm{ha}^{-1}, P<0.001\right)$.

\section{Forest composition}

The magnitude of tree species compositional change varied by size class and burn unit. The aspen-oak unit had the largest changes in relative density and most compositional change occurred in the seedling and sapling strata (Fig. 3). After two prescribed fires, red maple (Acer rubrum L.) seedling relative density decreased by $49 \%$ and black oak (Quercus velutina Lam.) increased by $29 \%$, becoming the dominant seedling species. Other seedling shifts in the aspen-oak unit included slight increases in northern red oak (Quercus rubra L.; +9\%), white oak (Quercus alba L.; $+11 \%$ ), and quaking aspen (Populus tremuloides Michx.; $+19 \%)$ following prescribed fire; and decreases in cherry $(-18 \%)$. The top four most abundant pre-fire seedlings were red maple, cherry, serviceberry, and white oak. After two fires, the top four were black oak, red maple, quaking 


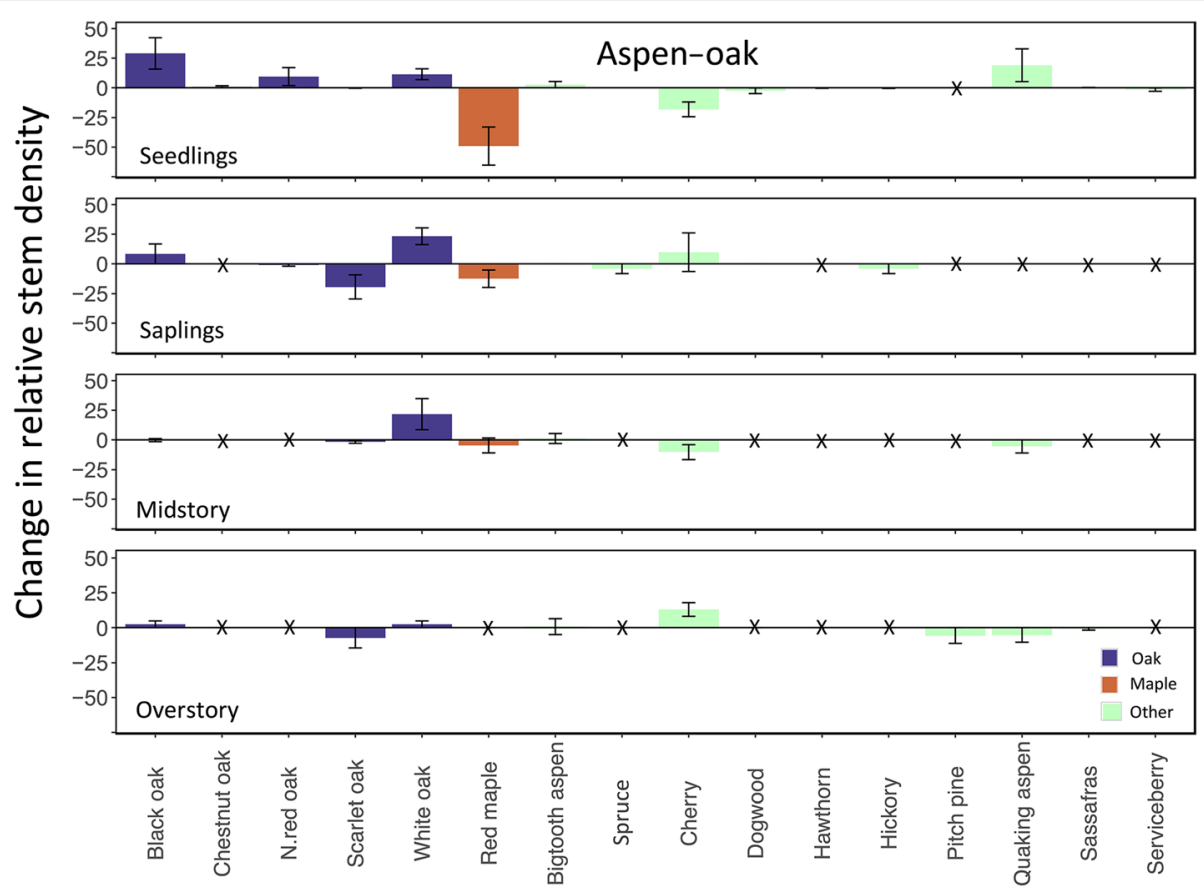

Fig. 3 Change in relative stem density between 2013 and 2018 (five growing seasons after initial prescribed fire) in the aspen-oak unit of State Game Lands 176, Pennsylvania, USA, where we measured changes in forest structure and composition after prescribed fire. Error bars represent standard error of the mean. "X" indicates that a given species was not present within a specific tree size class. N. red oak = northern red oak

aspen, and white oak. At the sapling level, white oak had the largest increase in relative density $(+23 \%)$ and was the most abundant sapling in the aspen-oak unit after two fires. Additional increases occurred for black oak $(+8 \%)$ and, after two fires, cherry was the only other tree present in the sapling layer. There were minor changes in relative density of midstory and overstory trees and there were no changes in the top four species in these size classes over the sample period. The most abundant midstory tree in the aspen-oak unit was cherry, followed by white oak, bigtooth aspen (Populus grandidentata Michx.), and red maple. The overstory was dominated by bigtooth aspen followed by a mix of cherry, scarlet oak (Quercus coccinea Muenchh), and white oak.

In comparison to the aspen-oak unit, seedling abundance by species in the mixed-oak unit barely changed (Fig. 4). Both before prescribed fire and eight years post fire, the three most abundant seedling species were red maple, chestnut oak (Quercus montana Willd.), and serviceberry. No species had a relative density change more than $9 \%$ at the seedling level. Sapling dominance in the mixed-oak unit shifted from red maple to sassafras (Sassafras albidum [Nutt.] Nees) between 2009 and 2018. Although red maple saplings were still the second most abundant species, they dropped in relative abundance by $41 \%$ and sassafras increased by 35\%. Minor increases in sapling abundance occurred for black oak $(+6 \%)$ and hickory
$(+10 \%)$ with decreases measured in chestnut oak $(-2 \%)$, scarlet oak $(-3 \%)$, and white oak $(-5 \%)$. Similar to the aspen-oak unit, the midstory and overstory trees in the mixed-oak unit showed little change in relative abundance. Both before and eight years after fire, the midstory was dominated by red maple, hickory, sassafras, and white oak. White oak dominated the overstory pre fire but was second to red maple post fire. Bigtooth aspen remained the third most abundant overstory tree and chestnut oak was replaced by black oak as the fourth most abundant.

On the unburned sites (Fig. 5), red maple and white oak seedling abundance decreased over six growing seasons but not by large amounts $(<9 \%)$. Red maple remained as the most dominant seedling species over time. Sapling, midstory, and overstory tree relative density did not notably change in unburned plots over time.

\section{Discussion}

Following prescribed fires, these Eastern mixed-oak and aspen-oak forests experienced shifts in species composition and changes in size-class structure resulting from post-fire mortality and forest regrowth. Large post-fire reductions of saplings (80 to $91 \%$ ) and midstory trees (46\%) substantially decreased the density of smaller-diameter stems. Prescribed fire effectively removed stems $<10 \mathrm{~cm}$ DBH likely due to their thinner bark and lower crown heights, which made them more susceptible to 


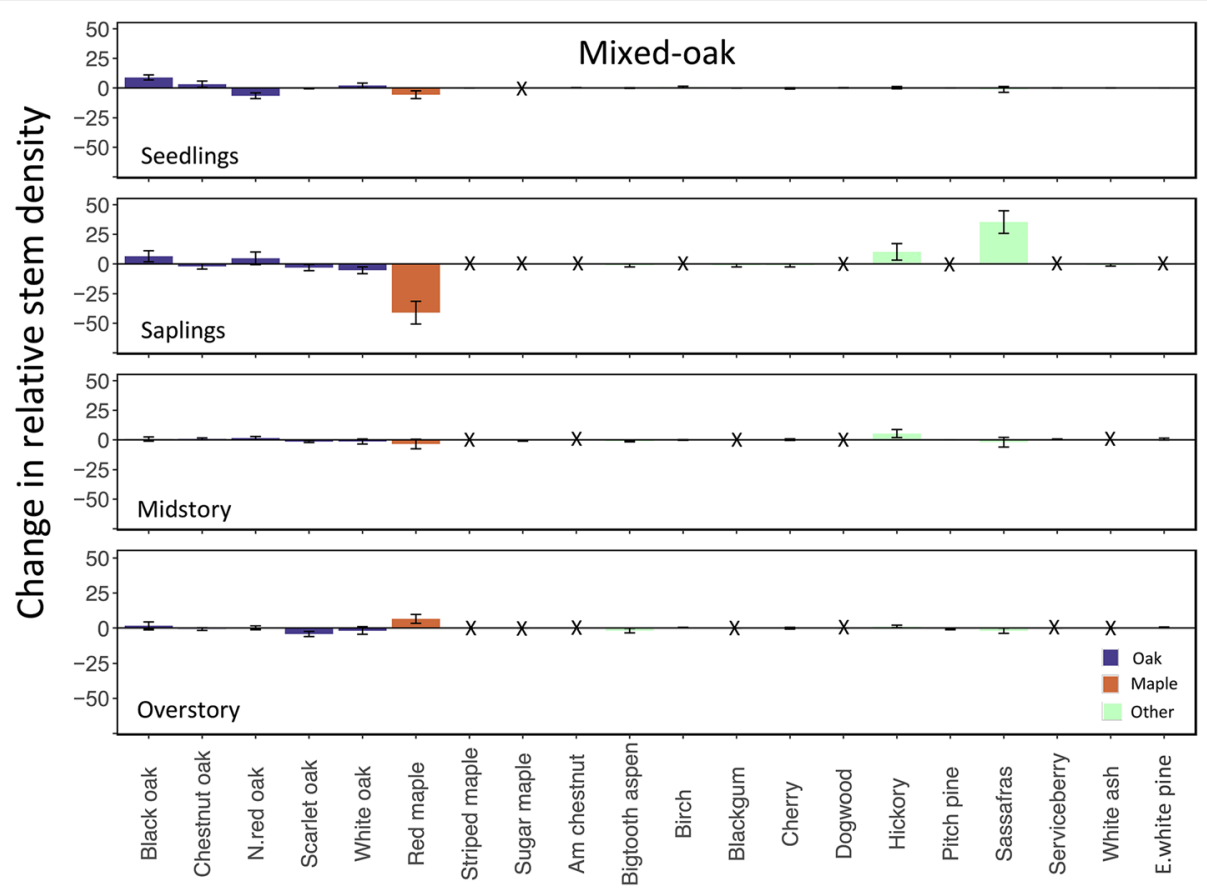

Fig. 4 Change in relative density between 2009 and 2018 (eight years after prescribed fire) in the mixed-oak unit of State Game Lands 176, Pennsylvania, USA, where we measured changes in forest structure and composition after prescribed fire. Error bars represent standard error of the mean. " $X$ " indicates that a given species was not present within a specific tree size class. N. red oak = northern red oak; $E$. white pine $=$ eastern white pine

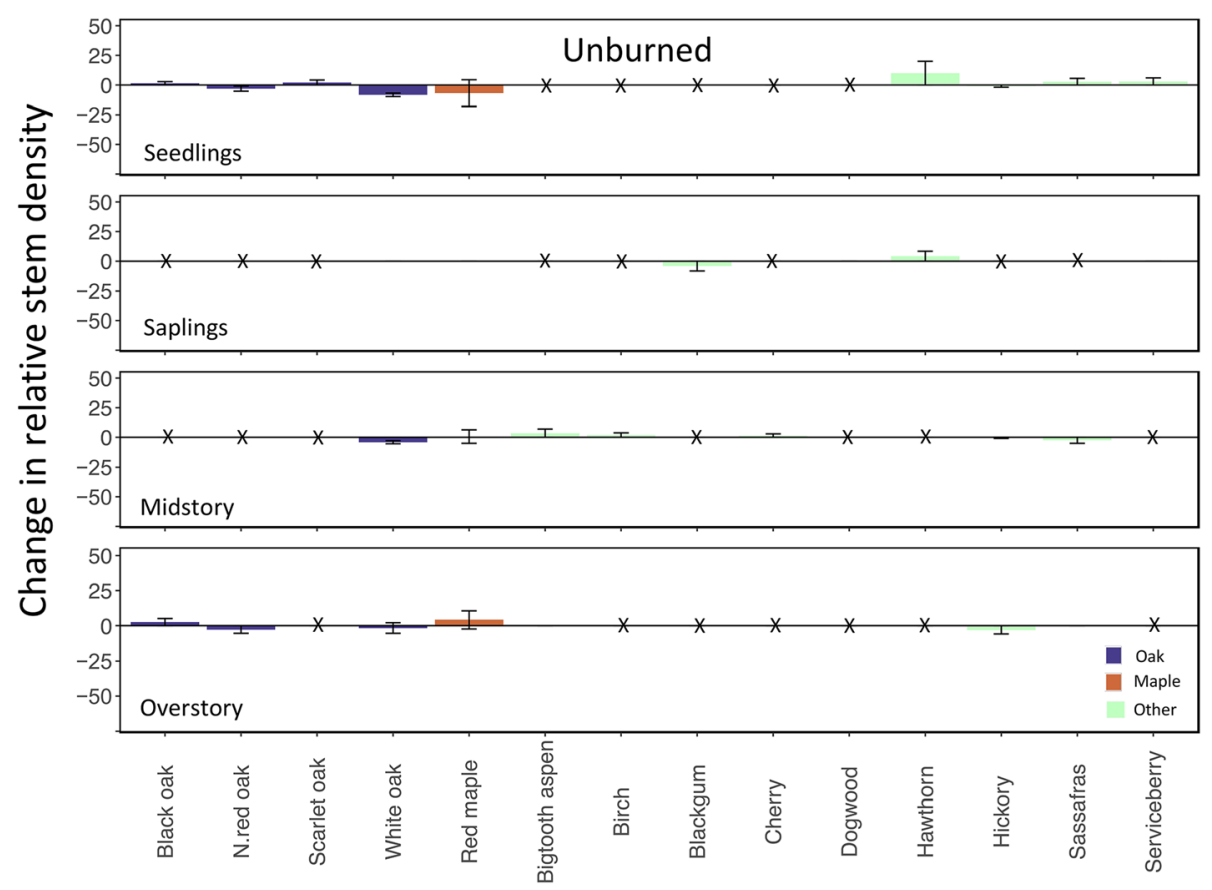

Fig. 5 Change in relative density between 2009 and 2014 in the unburned forests of State Game Lands 176, Pennsylvania, USA, where we measured changes in forest structure and composition after prescribed fire. Error bars represent standard error of the mean. " $X$ " indicates that a given species was not present within a specific tree size class. N. red oak = northern red oak 
fire damage than larger-diameter trees. Seedling density increased potentially due to basal sprouting from belowground energy stores (Blankenship and Arthur 2006), temporarily increased sunlight on the forest floor (Chiang et al. 2005), and a modified seed bed due to litter and duff consumption (Arthur et al. 2017). Our findings are consistent with prescribed fire studies in other Eastern deciduous forests (Peterson and Reich 2001; Schwilk et al. 2009; Hutchinson et al. 2012; Arthur et al. 2015; Knapp et al. 2015) that show that single, low-severity burns lead to similar structural changes across regions, but compositional changes require repeat burns or pre-fire management (Brose et al. 2013). However, in contrast to similar studies (Franklin et al. 2003; Blankenship and Arthur 2006), we found that, after a single prescribed fire, overstory stem density decreased (by $12 \%$ in the mixed-oak unit) over eight years. At the same time, overstory basal area increased, likely as a result of reduced competition and increased post-fire resource availability. The bulk of structural changes occurred between two and five years post fire; however, response varied among tree species.

Species compositional changes were greatest in the aspenoak unit that experienced a combination of pre-fire thinning and repeat burning. Among tree seedlings and saplings, the relative abundance of maple decreased and the abundance of oak increased after prescribed fire. However, the response of individual species was nuanced; for example, in both mixedoak and aspen-oak units, black oak increased or maintained abundance across all size classes, whereas saplings and overstory stems of scarlet oak, a species with thinner bark (Chamberlain and Meyer 1950; Spalt and Reifsnyder 1962), decreased. White oak responded differently between the two units with clear increases at all size classes in the aspen-oak unit and steady or decreasing abundance in the mixed-oak unit. Both northern red oak and chestnut oak abundance remained constant regardless of size class and burn unit. Interspecific variation in post-fire response is due to multiple direct and indirect fire effects (Hood et al. 2018) such as timing of burn and tree regeneration stage (Arthur et al. 2012), forest floor light availability (Dillaway et al. 2007), and differences in tree bark thickness (Spalt and Reifsnyder 1962; Miles and Smith 2009; Hammond et al. 2015). In general, trees with thinner bark are more vulnerable to fire (Pellegrini et al. 2017). However, large-diameter, thinbarked trees such as maple can withstand low-severity prescribed fire (Keyser et al. 2018), and in the mixedoak unit, overstory red maple trees increased in relative abundance following one prescribed fire.

Although maple and oak made up a large component of the forests in this study, a suite of other species and genera were present. Of these, sassafras, hickory, quaking aspen, and cherry had notable changes in relative abundance in at least one size class. Sassafras abundance increased in the mixed-oak sapling layer eight years after fire and went from the fifth most abundant to the first most abundant species. Sassafras's high growth rate and opportunistic regeneration post fire (Iverson et al. 1999) account for this compositional change. Additionally, hickory saplings increased in the mixed-oak unit and became the fourth most abundant species in the sapling size class, supporting the prescribed fire objective to promote hickory at various stages of succession in the mixed-oak unit.

Within the aspen-oak unit, quaking aspen, a species with root suckers stimulated by fire (Iverson et al. 1999), increased relative abundance in the seedling category one year after the second burn; however, the biggest non-oak, non-maple changes were found in cherry (Prunus sp.) trees. After two fires and five years, overstory cherry trees increased in abundance while cherry seedlings declined. Although cherry trees, like maple, are considered pyrophobic (Nowacki and Abrams 2015) or fire-intolerant, the two genera differ in their shade tolerance (Knott et al. 2019), with maple growing better in shade than cherry. Any post-fire increases in forest floor light availability were likely temporary due to rapid growth of forest shrubs (Chiang et al. 2005) and living overstory trees, effectively limiting cherry regeneration and highlighting how fire and shade tolerance interact to influence post-fire vegetation growth over time.

Forests in this study are managed to "protect wildlife and their habitats" (Pennsylvania Game Commission 2020) with prescribed fire objectives focused on maintaining overstory oak trees and top-killing young maple, birch, and aspen. Overstory oak increased $27 \%$ in the aspen-oak unit but decreased $24 \%$, primarily among scarlet oaks, in the mixedoak unit over eight years, partially achieving PGC burn objectives for overstory oak survival. Red maple seedlings and saplings decreased in relative abundance, birch and bigtooth aspen did not change, and quaking aspen seedling abundance increased where overstory aspen were dominant. Although the burn objectives were not met in full, post-fire reductions in red maple seedling and sapling trees were measured over eight years while red maple remained the dominant species on unburned plots. Species-specific responses to prescribed fire indicate a potential trajectory of compositional changes to be maintained through additional monitoring, treatments, and management.

Overall forest composition plays a key role in vegetationfire relationships, and localized studies, like ours, are necessary to measure the extent of forest heterogeneity following prescribed fire disturbance. The degree of compositional change following prescribed fire is determined by multiple interacting factors (Chazdon 2008; Stroud 2012; Chapman and McEwan 2016) and the aspen-oak forest, where pre-fire overstory thinning and two prescribed fires were used, had more pronounced compositional shifts than the single burn, 
mixed-oak forest. However, significant structural changes occurred in both forests after just one burn. Prescribed fire goals focused on changing forest structure can be achieved in varied mid-Atlantic oak forest types, while goals focused on compositional shifts should vary based on forest type, management history, and opportunity to apply multiple burns.

\section{Supplementary Information}

The online version contains supplementary material available at https://doi. org/10.1186/s42408-021-00093-5

Additional file 1. Prescribed fire information for five burns conducted between 2010 and 2017 within State Game Lands 176, Pennsylvania, USA. Our study measured forest structure and composition change for up to eight years after these prescribed fires. Asterisk $\left(^{*}\right)$ indicates information gathered from The Pennsylvania State Climatologist and collected in State College, Pennsylvania. Caret $(\wedge)$ indicates information visually measured post fire. NR stands for not recorded. All other information was collected by fire managers in the field.

\section{Acknowledgements}

The authors would like to thank the staff of the Pennsylvania Game Commission, namely P. Lupo, B. Stone, B. Jones, J. Wakefield, and E. Erdman, for use of the Continuous Forest Inventory data, access to field sites, and ease of partnership. We thank C. Lauvaux, E. Maynard-Bean, L. Onofrio, and S. Perkins for assisting with data collection over multiple years, as well as $L$. and E. Ryan for creating maps of our study area. Funding for this project was provided by the Joint Fire Science Program (Project: 16-1-02-5) and USDA National Institute of Food and Agriculture Federal Appropriations under Project PEN04658 and Accession number 1016433

\section{Authors' contributions}

CLD: data collection, statistical analyses, interpretation of data, manuscript preparation and editing. AHT: study design, data collection, interpretation of data, manuscript editing. EAHS: study design, interpretation of data, manuscript editing. JK: interpretation of data, manuscript editing. MWK: study design, data collection, interpretation of data, manuscript preparation and editing. All authors read and approved the final manuscript.

\section{Funding}

This project was funded by the Joint Fire Science Program (Project: 16-1-025) and USDA National Institute of Food and Agriculture Federal Appropriations under Project PEN04658 and Accession number 1016433.

\section{Availability of data and materials}

The datasets used or analyzed during the current study are available from the corresponding author on reasonable request.

\section{Ethics approval and consent to participate}

Not applicable.

\section{Consent for publication}

Not applicable.

\section{Competing interests}

The authors declare that they have no competing interests.

\section{Author details}

${ }^{1}$ Department of Ecosystem Science and Management, The Pennsylvania State University, University Park, Pennsylvania 16802, USA. ${ }^{2}$ Department of Geography and Earth and Environmental Systems Institute, The Pennsylvania State University, University Park, Pennsylvania 16802, USA.
Received: 5 November 2020 Accepted: 4 February 2021

Published online: 23 April 2021

\section{References}

Abrams, M.D. 2003. Where has all the white oak gone? BioScience 53: 927-939. https://doi.org/10.1641/0006-3568(2003)053[0927:WHATWO]2.0.CO;2.

Abrams, M.D., and S.E. Johnson. 2014. Impacts of early homestead abandonment on forests and soils at Scotia Barrens, central Pennsylvania: implications for altered and arrested vegetation development. Human Ecology 42: 793-799. https://doi.org/10.1007/s10745-014-9680-6.

Abrams, M.D., and G.J. Nowacki. 2019. Global change impacts on forest and fire dynamics using paleoecology and tree census data for eastern North America. Annals of Forest Science 76: 1-23. https://doi.org/10.1007/s13595-01 8-0790-y

Albrecht, M.A., and B.C. McCarthy. 2006. Effects of prescribed fire and thinning on tree recruitment patterns in central hardwood forests. Forest Ecology and Management 226: 88-103. https://doi.org/10.1016/j.foreco.2005.12.061.

Alexander, H.D., and M.A. Arthur. 2010. Implications of a predicted shift from upland oaks to red maple on forest hydrology and nutrient availability. Canadian Journal of Forest Research 40: 716-726. https://doi.org/10.1139/X10029

Alexander, H.D., and M.A. Arthur. 2014. Increasing red maple leaf litter alters decomposition rates and nitrogen cycling in historically oak-dominated forests of the Eastern U.S. Ecosystems 17: 1371-1383. https://doi.org/10.1007/ s10021-014-9802-4.

Alexander, H.D. M.A. Arthur, D.L. Loftis, and S.R. Green. 2008. Survival and growth of upland oak and co-occurring competitor seedlings following single and repeated prescribed fires. Forest Ecology and Management 256: 1021-1030. https://doi.org/10.1016/j.foreco.2008.06.004.

Arthur, M.A., H.D. Alexander, D.C. Dey, C.J. Schweitzer, and D.L. Loftis. 2012. Refining the oak-fire hypothesis for management of oak-dominated forests of the eastern United States. Journal of Forestry 110: 257-266. https://doi. org/10.5849/jof.11-080.

Arthur, M.A., B.A. Blankenship, A. Schorgendorfer, and H.D. Alexander. 2017 Alterations to the fuel bed after single and repeated prescribed fires in an Appalachian hardwood forest. Forest Ecology and Management 403: 126-136. https://doi.org/10.1016/j.foreco.2017.08.011.

Arthur, M.A., B.A. Blankenship, A. Schorgendorfer, D.L. Loftis, and H.D. Alexander. 2015. Changes in stand structure and tree vigor with repeated prescribed fire in an Appalachian hardwood forest. Forest Ecology and Management 340: 46 61. https://doi.org/10.1016/j.foreco.2014.12.025

Bates, D., M. Maechler, B. Bolker, and S. Walker. 2015. Fitting linear mixed-effects models using Ime4. Journal of Statistical Software 67: 1-48. https://doi.org/1 0.18637/jss.v067.i01

Blankenship, B.A., and M.A. Arthur. 2006. Stand structure over 9 years in burned and fire-excluded oak stands on the Cumberland Plateau, Kentucky. Forest Ecology and Management 225: 134-145. https://doi.org/10.1016/j.foreco.2 005.12.032.

Brando, P.M., D.C. Nepstad, J.K. Balch, B. Bolker, M.C. Christman, M. Coe, and F.E. Putz. 2012. Fire-induced tree mortality in a neotropical forest: the roles of bark traits, tree size, wood density and fire behavior. Global Change Biology 18: 630-641. https://doi.org/10.1111/j.1365-2486.2011.02533.x.

Brose, P.H. 2014. Development of prescribed fire as a silvicultural tool for the upland oak forests of the eastern United States. Journal of Forestry 112: 525533. https://doi.org/10.5849/jof.13-088.

Brose, P.H., D.C. Dey, R.J. Phillips, and T.A. Waldrop. 2013. A meta-analysis of the fire-oak hypothesis: does prescribed burning promote oak reproduction in eastern North America? Forest Science 59: 322-334. https://doi.org/10.5849/ forsci.12-039.

Brose, P.H., K.W. Gottschalk, S.B. Horsley, P.D. Knopp, J.N. Kochenderfer, B.J. McGuinness, G.W. Miller, T.E. Ristau, S.H. Stoleson, and S.L. Stout. 2008. Prescribing regeneration treatments for mixed-oak forests in the Mid-Atlantic Region. Newtown Square: USDA Forest Service, Northern Research Station, General Technical Report NRS-GTR-33.

Bureau of Wildlife Habitat Management. 2013. Manual of procedure for the continuous forest inventory of forest wildlife habitat resources. 3rd ed, 68. Harrisburg: Commonwealth of Pennsylvania Game Commission, Forestry Division.

Chamberlain, E.B., and H.A. Meyer. 1950. Bark volume in cordwood. TAPPI 33: 554-555. 
Chapman, J.l., and R.W. McEwan. 2016. Thirty years of compositional change in an old-growth temperate forest: the role of topographic gradients in oak-maple dynamics. PLOS ONE 11: 1-17. https://doi.org/10.1371/journal.pone.0160238.

Chazdon, R.L. 2008. Beyond deforestation: restoring forests and ecosystem services on degraded lands. Science 320: 1458-1460. https://doi.org/10.1126/ science. 1155365 .

Chiang, J.M., M.A. Arthur, and B.A. Blankenship. 2005. The effect of prescribed fire on gap fraction in an oak forest on the Cumberland Plateau. The Journal of the Torrey Botanical Society 132: 432-441. https://doi.org/10.3159/1095-5674 (2005)132[432:TEOPFO]2.0.CO;2.

Dey, D.C. 2014. Sustaining oak forests in eastern North America: regeneration and recruitment, the pillars of sustainability. Forest Science 60: 926-942. https:// doi.org/10.5849/forsci.13-114.

Dillaway, D.N., J.W. Stringer, and L.K. Rieske. 2007. Light availability influences root carbohydrates, and potentially vigor, in white oak advance regeneration. Forest Ecology and Management 250: 227-233. https://doi.org/10.1016/j. foreco.2007.05.019.

Donovan, G.H., and T.C. Brown. 2007. Be careful what you wish for: the legacy of Smokey Bear. Frontiers in Ecology and the Environment 5: 73-79. https://doi. org/10.1890/1540-9295(2007)5[73:BCWYWF]2.0.CO;2.

Drummond, M.A., and T.R. Loveland. 2010. Land-use pressure and a transition to forest-cover loss in the eastern United States. BioScience 60: 286-298. https:// doi.org/10.1525/bio.2010.60.4.7.

Fan, Z., Z. Ma, D.C. Dey, and S.D. Roberts. 2011. Response of advance reproduction of oaks and associated species to repeated prescribed fires in upland oak-hickory forests, Missouri. Forest Ecology and Management 266: 160-169. https://doi.org/10.1016/j.foreco.2011.08.034.

Franklin, S.B., P.A. Robertson, and J.S. Fralish. 2003. Prescribed burning effects on upland Quercus forest structure and function. Forest Ecology and Management 184: 315-335. https://doi.org/10.1016/S0378-1127(03)00153-1.

Graham, J.B., and B.C. McCarthy. 2006. Forest floor fuel dynamics in mixed-oak forests of south-eastern Ohio. International Journal of Wildland Fire 15: 479488. https://doi.org/10.1071/WF05108.

Hammond, D.H., J.M. Varner, J.S. Kush, and Z. Fan. 2015. Contrasting sapling bark allocation of five southeastern USA hardwood tree species in a fire prone ecosystem. Ecosphere 6: 1-13. https://doi.org/10.1890/ES15-00065.1.

Hood, S.M., J.M. Varner, P. van Mantgem, and C.A. Cansler. 2018. Fire and tree death: understanding and improving modeling of fire-induced tree mortality. Environmental Research Letters 13. https://doi.org/10.1088/1748-9326/aae934.

Huddle, J.A., and S.G. Pallardy. 1999. Effect of fire on survival and growth of Acer rubrum and Quercus seedlings. Forest Ecology and Management 118: 49-56. https://doi.org/10.1016/S0378-1127(98)00485-X.

Hutchinson, T.F., R.E.J. Boerner, S. Sutherland, E.K. Sutherland, M. Ortt, and L.R. Iverson. 2005. Prescribed fire effects on the herbaceous layer of mixed-oak forests. Canadian Journal of Forest Research: 35. https://doi.org/10.1139/x04-189.

Hutchinson, T.F., D.A. Yaussy, R.P. Long, J. Rebbeck, and E.K. Sutherland. 2012. Long-term (13-year) effects of repeated prescribed fires on stand structure and tree regeneration in mixed-oak forests. Forest Ecology and Management 286: 87-100. https://doi.org/10.1016/j.foreco.2012.08.036.

Iverson, L.R., T.F. Hutchinson, A.M. Prasad, and M.P. Peters. 2008. Thinning, fire, and oak regeneration across a heterogeneous landscape in the eastern U.S. 7-year results. Forest Ecology and Management 255: 3035-3050. https://doi. org/10.1016/j.foreco.2007.09.088.

Iverson, L.R., A.M. Prasad, B.J. Hale, and E. Kennedy Sutherland. 1999. Atlas of current and potential future distributions of common trees of the eastern United States. Radnor: USDA Forest Service, Northeastern Research Station, General Technical Report NE-265.

Keeley, J.E., J.G. Pausas, P.W. Rundel, W.J. Bond, and R.A. Bradstock. 2011. Fire as an evolutionary pressure shaping plant traits. Trends in Plant Science 16: 406411. https://doi.org/10.1016/j.tplants.2011.04.002.

Keyser, T.L., M. Arthur, and D.L. Loftis. 2017. Repeated burning alters the structure and composition of hardwood regeneration in oak-dominated forests of eastern Kentucky, USA. Forest Ecology and Management 393: 1-11. https:// doi.org/10.1016/j.foreco.2017.03.015.

Keyser, T.L., V.L. McDaniel, R.N. Klein, D.G. Drees, J.A. Burton, and M.M. Forder. 2018. Short-term stem mortality of 10 deciduous broadleaved species following prescribed burning in upland forests of the southern US. International Journal of Wildland Fire 27: 42-51. https://doi.org/10.1071/WF17058.

Klimkos, M.J. 2017. The fires of Penn's woods. Carlisle: Cooks Run Publications.

Knapp, B.O., K. Stephan, and J.A. Hubbart. 2015. Structure and composition of an oak-hickory forest after over 60 years of repeated prescribed burning in
Missouri, U.S.A. Forest Ecology and Management 344: 95-109. https://doi.org/1 0.1016/j.foreco.2015.02.009.

Knapp, E.E., B.L. Estes, and C.N. Skinner. 2009. Ecological effects of prescribed fire season: a literature review and synthesis for managers. Albany: USDA Forest Service, Pacific Southwest Research Station, General Technical Report PSWGTR-224.

Knott, J.A., J.M. Desprez, C.M. Oswalt, and S. Fei. 2019. Shifts in forest composition in the eastern United States. Forest Ecology and Management 433: 176-183. https://doi.org/10.1016/j.foreco.2018.10.061.

Kreye, J.K., J.M. Varner, J.K. Hiers, and J. Mola. 2013. Toward a mechanism for eastern North American forest mesophication: differential litter drying across 17 species. Ecological Applications 23: 1976-1986. https://doi.org/10.1890/130503.1.

Lafon, C.W., A.T. Naito, H.D. Grissino-Mayer, S.P. Horn, and T.A. Waldrop. 2017. Fire history of the Appalachian Region: a review and synthesis. Asheville: USDA Forest Service, Southern Research Station, General Technical Report SRS-219.

Lenth, R.V. 2016. Least-squares means: the R package Ismeans. Journal of Statistical Software 69: 1-33.

Marschall, J.M., M.C. Stambaugh, B.C. Jones, R.P. Guyette, P.H. Brose, and D.C. Dey, 2016. Fire regimes of remnant pitch pine communities in the Ridge and Valley Region of central Pennsylvania, USA. Forests 7: 1-16. https://doi.org/1 0.3390/f7100224.

McEwan, R.W., J.M. Dyer, and N. Pederson. 2011. Multiple interacting ecosystem drivers: toward an encompassing hypothesis of oak forest dynamics across eastern North America. Ecography 34: 244-256. https://doi.org/10.1111/j.16000587.2010.06390.x

Miles, P.D., and W.B. Smith. 2009. Specific gravity and other properties of wood and bark for 156 tree species found in North America. Newtown Square: USDA Forest Service, Northern Research Station, Research Note NRS-38.

Mitchell, R.J., J.K. Hiers, J. O'Brien, and G. Starr. 2009. Ecological forestry in the Southeast: understanding the ecology of fuels. Journal of Forestry 107: $391-$ 397. https://doi.org/10.1093/jof/107.8.391.

National Interagency Fire Center. 2017. National report of wildland fires and acres burned by state. https://www.nifc.gov/firelnfo/firelnfo_stats_prescribed.html. Accessed 22 Nov 2019.

Nowacki, G.J., and M.D. Abrams. 2008. The demise of fire and "mesophication" of forests in the eastern United States. BioScience 58: 123-138. https://doi.org/1 $0.1641 / B 580207$.

Nowacki, G.J., and M.D. Abrams. 2015. Is climate an important driver of postEuropean vegetation change in the Eastern United States? Glob Change Biol 21: 314-334.

O'Neil, M. M, 2006. Impacts of land use history and edaphic factors on the scotia barrens of central Pennsylvania. M.Sc. Thesis. The Pennsylvania State University.

PA DCNR. 2015. Pennsylvania prescribed fire data 2010-2015. https://www.denr.pa. gov/Conservation/ForestsAndTrees/PrescribedFire. Accessed 22 Nov 2019.

Palmer, W.L. 2000. The barrens grouse habitat management study, State Game Lands no. 176. Pennsylvania Game Commission, Bureau of Wildlife Management, Project Annual Job Report-06290.

Pausas, J.G. 2015. Bark thickness and fire regime. Functional Ecology 29: 315-327. https://doi.org/10.1111/1365-2435.12372.

Pellegrini, A.F.A., W.R.L. Anderegg, C.E.T. Paine, W.A. Hoffman, T. Kartzinel, S.S. Rabin, D. Sheil, A.C. Franco, and S.W. Pacala. 2017. Convergence of bark investment according to fire and climate structures ecosystem vulnerability to future change. Ecology Letters 20: 307-316. https://doi.org/10.1111/ele.12725.

Pennsylvania Game Commission. 2020. About Us: Mission. https://www.pgc.pa. gov/InformationResources/AboutUs/Pages/default.aspx. Accessed 26 Oct 2020.

Pennsylvania General Assembly. House. Prescribed Burning Practices Act of 2009. HB 262. Sess. of 2009. http://www.docs.dcnr.pa.gov/cs/groups/public/ documents/document/dcnr_003985.pdf. Accessed 20 May 2019.

Peterson, D.W., and P.B. Reich. 2001. Prescribed fire in oak savanna: fire frequency effects on stand structure and dynamics. Ecological Applications 11: 914-927. https://doi.org/10.1890/1051-0761(2001)011[0914:PFIOSF]2.0.CO;2.

R Core Team. 2018. R: a language and environment for statistical computing. R Foundation for Statistical Computing, Vienna, Austria. https://www.Rproject.org/.

Ryan, K.C., E.E. Knapp, and J.M. Varner. 2013. Prescribed fire in North American forests and woodlands: history, current practice, and challenges. Frontiers in Ecology and the Environment 11: 15-24. https://doi.org/10.1890/120329.

Schwilk, D.W., J.E. Keeley, E.E. Knapp, J. Mclver, J.D. Bailey, C.J. Fettig, C.E. Fielder, R. J. Harrod, J.J. Moghaddas, K.W. Outcalt, C.N. Skinner, S.L. Stephens, T.A. 
Waldrop, D.A. Yaussy, and A. Youngblood. 2009. The national Fire and Fire Surrogate study: effects of fuel reduction methods on forest vegetation structure and fuels. Ecological Applications 19: 285-304. https://doi.org/10.1 890/07-1747.1.

Smithwick, E.A.H., M. Kaye, A. Taylor, P. Newman, K. Zipp, and H. Wu. 2020. Firescapes in the mid-Atlantic: mismatches between social perceptions and prescribed fire use. Joint Fire Science Program, Project Final Report-16-1-02-5. Spalt, K.W., and W.E. Reifsnyder. 1962. Bark characteristics and fire resistance: a literature survey. New Orleans: USDA Forest Service, Southern Forest Experiment Station.

Stambaugh, M.C., J.M. Marschall, E.R. Abadir, B.C. Jones, P.H. Brose, D.C. Dey, and R.P. Guyette. 2018. Wave of fire: an anthropogenic signal in historical fire regimes across central Pennsylvania, USA. Ecosphere 9: 1-28. https://doi.org/1 0.1002/ecs2.2222.

Stambaugh, M.C., J.M. Varner, R.F. Noss, D.C. Dey, N.L. Christensen, R.F. Baldwin, R. P. Guyette, B.B. Hanberry, C.A. Harper, S.G. Lindblom, and T.A. Waldrop. 2015. Clarifying the role of fire in the deciduous forests of eastern North America: reply to Matlack. Conservation Biology 29: 942-946. https://doi.org/10.1111/ cobi.12473.

Stroud, E. 2012. Nature next door: cities and trees in the American northeast. Seattle: University of Washington Press.

The Pennsylvania State Climatologist. 2019. State College city information. http:/ www.climate.psu.edu/data/city_information/index.php?city=unv\&page=dwa \&type=big7. Accessed 5 Jun 2019.

Tiribelli, F., T. Kitzberger, and J.M. Morales. 2018. Changes in vegetation structure and fuel characteristics along post-fire succession promote alternative stable states and positive fire-vegetation feedbacks. Journal of Vegetation Science 29: 147-156. https://doi.org/10.1111/jvs.12620.

USDA Web Soil Survey. 2019. Web Soil Survey (WSS). https://websoilsurvey.sc.egov. usda.gov. Accessed 14 Sept 2020.

Varner, J.M., M.A. Arthur, S.L. Clark, D.C. Dey, J.L. Hart, and C.J. Schweitzer. 2016. Fire in eastern north american oak ecosystems: filling the gaps. Fire Ecology 12: 1-6. https://doi.org/10.4996/fireecology.1202001.

\section{Publisher's Note}

Springer Nature remains neutral with regard to jurisdictional claims in published maps and institutional affiliations.

\section{Submit your manuscript to a SpringerOpen ${ }^{\circ}$ journal and benefit from:}

- Convenient online submission

- Rigorous peer review

- Open access: articles freely available online

- High visibility within the field

- Retaining the copyright to your article

Submit your next manuscript at $\boldsymbol{\nabla}$ springeropen.com 